\title{
Renal sympathetic denervation for resistant hypertension: where do we stand after more than a decade
}

\author{
Denervação simpática renal para hipertensão resistente: situação \\ depois de mais de uma década
}

\section{Authors}

Marco Antônio Peliky Fontes ${ }^{1}$

Lucas Alexandre Santos

Marzano ${ }^{2}$

Carina Cunha Silva ${ }^{1}$

Ana Cristina Simões e Silva ${ }^{2}$ iD

\begin{abstract}
${ }^{1}$ Universidade Federal de Minas Gerais, Departamento de Fisiologia e Biofísica, Belo Horizonte, MG, Brasil.

${ }^{2}$ Universidade Federal de Minas Gerais, Faculdade de Medicina, Departamento de Pediatria, Belo Horizonte, Brasil.
\end{abstract}

Submitted on: 10/24/2018. Approved on: 08/18/2019.

\section{Correspondence to:}

Ana Cristina Simões e Silva.

E-mail: acssilva@hotmail.com

DOI: 10.1590/2175-8239-JBN-2018-0213

\section{Abstract}

Despite the current availability of safe and efficient drugs for treating hypertension, a substantial number of patients are drug-resistant hypertensives. Aiming this condition, a relatively new approach named catheter-based renal denervation was developed. We have now a clinically relevant time window to review the efficacy of renal denervation for treating this form of hypertension. This short review addresses the physiological contribution of renal sympathetic nerves for blood pressure control and discusses the pros and cons of renal denervation procedure for the treatment of resistant hypertension.

Keywords: Hypertension; Sympathetic nervous system; Sympathectomy; Denervation; Renal hypertension.

\section{Resumo}

Em que pese a atual disponibilidade de medicamentos seguros e eficientes para o tratamento da hipertensão, um número significativo de pacientes sofre de hipertensão arterial resistente a tratamento medicamentoso. Em vista dessa condição, foi desenvolvida uma abordagem relativamente nova, denominada denervação renal por cateter. Dispomos atualmente de uma janela de tempo clinicamente relevante para analisar a eficácia da denervação renal no tratamento dessa modalidade de hipertensão. A presente revisão aborda a contribuição fisiológica dos nervos renais simpáticos no controle da pressão arterial e discute os prós e contras do procedimento de denervação renal no tratamento da hipertensão resistente.

Palavras-chave: Hipertensão; Sistema Nervoso Simpático; Simpatectomia; Denervação; Hipertensão renal.

\section{INTRODUCTION}

Currently, hypertension is a global public health problem. In the United States, the 2017 Heart Disease and Stroke Statistics Update shows that about 85.7 million, or 34 percent, of American adults have high blood pressure ${ }^{1}$. In China, the adjusted prevalence of hypertension is $29.6 \%^{2}$. In Brazil, 36 million people are affected, an estimated prevalence of $32.5 \%$, contributing directly or indirectly to $50 \%$ of deaths due to cardiovascular disease ${ }^{3}$. Therefore, the development of new pharmacological or non-pharmacological strategies for controlling blood pressure is extremely important.

Blood pressure is controlled, to a large extent, by sympathetic nerves, which are tonically active and define the sympathetic tone in heart, vessels, and kidneys ${ }^{4}$. Inactivation of specific central nervous system regions results in immediate fall in renal sympathetic nerve activity with consequent fall in blood pressure, and this effect is pronounced in the experimental model of essential hypertension ${ }^{5,6}$. The sympathetic innervation of the kidney plays an important role in all aspects of renal physiology, and renal sympathetic hyperactivity is considered central for human hypertension development and its progression ${ }^{7-9}$. In chronic kidney disease, renal nerves contribute to hypertension by increasing sympathoexcitation to other targets $^{10}$.

Presently, numerous effective anti-hypertensive drugs are available, including antiadrenergic, diuretics, ACE inhibitors, 
angiotensin receptor blockers, calcium-channel blockers, and anti-renin drugs. However, a significant number of patients with essential hypertension are drug-resistant, i.e., patients that are unable to achieve goal blood pressure levels despite usage of 3 different antihypertensive agents at the appropriate dosage ${ }^{11}$.

The need for an alternative treatment for severe resistant hypertension led to the development of radiofrequency renal denervation. The procedure consists of delivering radiofrequency energy into the lumen of renal arteries leading to thermal disruption of postganglionic sympathetic nerves directed to the kidney $^{12}$ (Figure 1A).

More than a decade after the first patient was treated with the radiofrequency catheter system, the efficacy of renal denervation is under consideration ${ }^{12,13}$. Findings of different clinical trials are quite different ${ }^{14}$ varying from a large reduction in ambulatory systolic blood pressure, reaching an average of $-20 \mathrm{mmHg}$ at 6 months as reported in early trials ${ }^{15,16}$ to an astonishing non-significant effect ${ }^{17}$. Of course, differences in blood pressure levels, medications, and procedures among trials might account for these discrepant results. However, a recent proof-of-concept trial for renal denervation published by Raymond Townsend and colleagues can bring additional light to this scenario. The results are modest but consistent (ambulatory systolic blood pressure $-5.5 \mathrm{mmHg}$ at 3 months), supporting the correlation between reduction in renal sympathetic tone and reduction in blood pressure ${ }^{18}$. It is important to highlight, however, that studies use a variety of techniques for renal sympathetic denervation (Table 1) and their different findings lead to different conclusions about the renal denervation, which increases the importance of this discussion. Thus, this is an appropriate time to review some physiological

Figure 1. Renal denervation (A) alters the sympathetic cross-talk between kidneys and the central nervous system interrupting both efferent and afferent signaling (B and C). A) Radiofrequency energy (represented by dotted circles) is delivered into the lumen of renal arteries leading to thermal disruption of postganglionic sympathetic nerves directed to the kidney. B) Arrows / lines represent action potentials travelling along efferent and afferent fibers; this signaling is interrupted by renal denervation. C) Functional aspects of renal innervation involving intact efferent and afferent fibers signaling. Efferent activity changes kidney function and altered kidney function stimulates afferent signals leading to inhibition of efferent signaling. See text for details. SNA = sympathetic nerve activity.

A) Renal dennervation

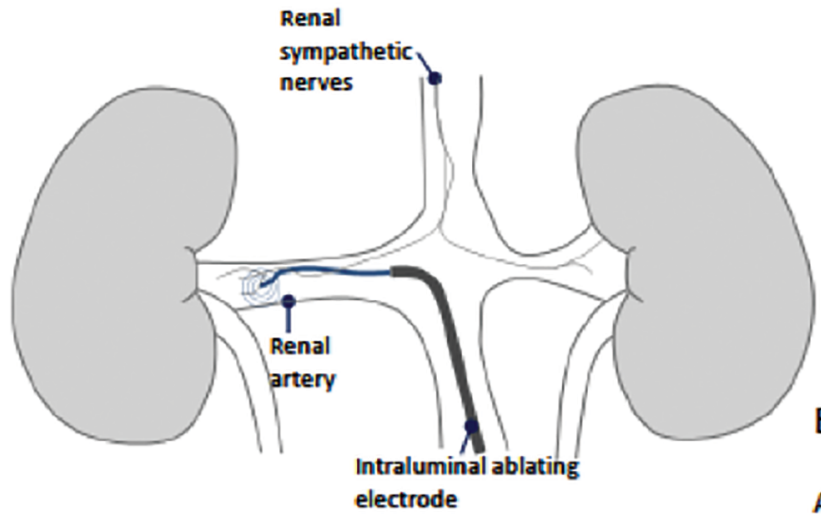

B) Renal nerve activity

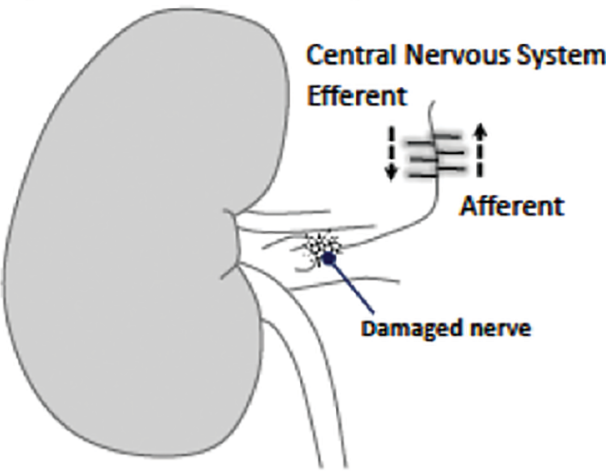

\section{C) Functional aspects of renal innervation}

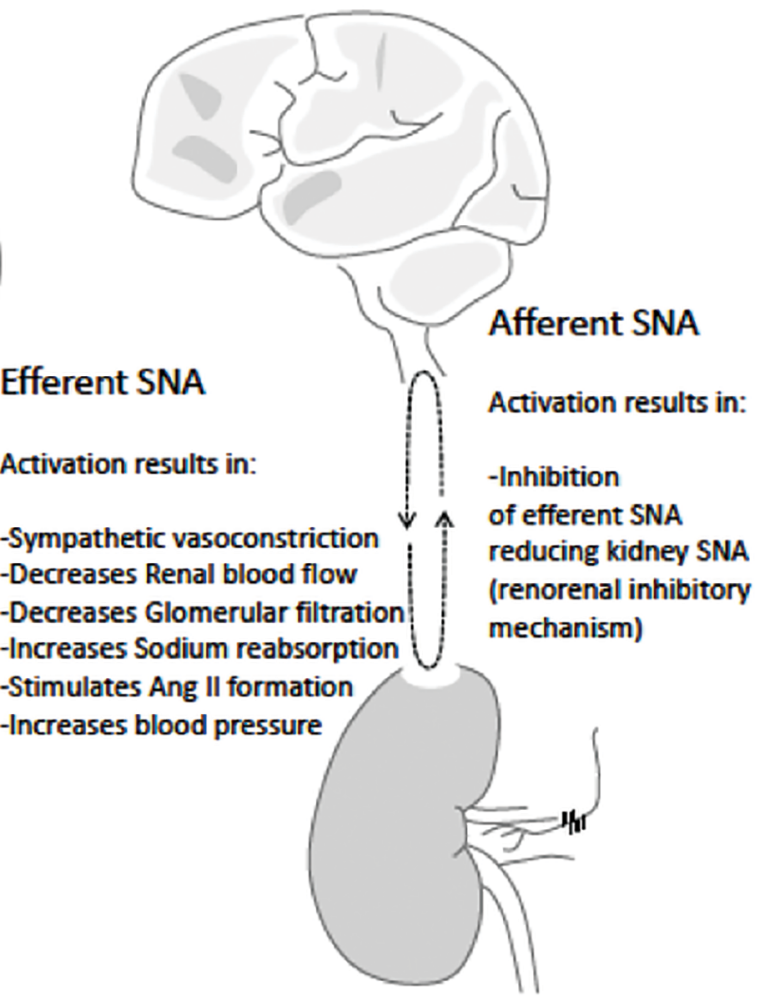


TABLE 1 EXPERIMENTAL AND CLINICAL STUDIES ON SYMPATHETIC RENAL DENERVATION

\begin{tabular}{lccc}
\hline Authors & Technique/ method & Species/Number & Result \\
\hline $\begin{array}{l}\text { Kandzari DE, Böhm M, } \\
\text { Mahfoud F, et al, on behalf } \\
\text { of the SPYRAL HTN-ON }\end{array}$ & Renal Denervation & Humans/n=80 & $\begin{array}{c}\text { This trial has shown significant } \\
\text { differences in favor of renal denervation } \\
\text { MED Trial Investigators }\end{array}$ \\
& & $\begin{array}{c}\text { after the procedure evaluated by 24-h } \\
\text { ambulatory measurements. (In favor) }\end{array}$
\end{tabular}

Azizi M, Schmieder, RE, Mahfoud F, et al, on behalf of the RADIANCE-HTN Investigators
Endovascular ultrasound rena denervation

The study concluded that the procedure was able to significantly reduce systolic and diastolic blood pressure between

the groups at 2 months after the procedure evaluated by 24-h ambulatory measurements. (In favor)

Townsend RR, Mahfoud F, Kandzari DE, et al. On behalf of the SPYRAL HTNOFF MED trial investigators Renal Denervation Humans $/ \mathrm{n}=80$ (2017)

Bhatt DL, M.D, MPH, et al. For the SYMPLICITY HTN-3 Investigators (2014)

Renal artery denervation Humans/n=535

This trial has shown significant differences in favor of renal denervation reported between the groups in the 3 months change in 24-h ambulatory measurements. (In favor)

This trial did not demonstrate a benefit of renal artery denervation on reduction in ambulatory $\mathrm{BP}$ in either the 24-h or day and night periods compared with sham. (Against)

Data from this animal experiment did not identify a clinically useful way of predicting the magnitude of the blood pressure fall that occurs after renal denervation. (Against)

Data from this study provides direct insight into the role of the vagal afferent outflow in the regulation of cardiovascular function in chronic kidney disease in males and females

(In favor)

Salman IM, Hildreth CM, Phillips JK. (2017)
Vagal afferent stimulation
Rats $/ \mathrm{n}=63$
Bilateral renal Rats $/ \mathrm{n}=15$

In fav

Goodwill VS, Terrill C, Hopewood I, Loewy AD, Knuepfer MM (2017)

Infusion of isotonic or hypertonic $\mathrm{NaCl}$
This experiment has shown that normal saline had little effect on afferent nerve activity, while hypertonic $\mathrm{NaCl}$ elicited an increase in renal afferent nerve activity. (In favor)

This study shows that an enhanced/ altered afferent renal input to the paraventricular nucleus in disease conditions such as chronic heart failure and hypertension may be involved in producing elevated sympathetic nerve activity commonly observed in these disease states. (In favor)

According to this review, endurance exercise training clearly lowers sympathetic activity in sympathoexcitatory disease states. It also influences many factors which may mediate a reduction in sympathetic activity However, the utility of endurance training as a countermeasure to alter sympathetic nerve activity in CKD patients remains to be determined (Inconclusive) 


\begin{tabular}{|c|c|c|c|}
\hline Olaf Grisk (2017) & $\begin{array}{l}\text { Bilateral renal } \\
\text { denervation }\end{array}$ & - & $\begin{array}{l}\text { According to this review, even if } \\
\text { new techniques were applied that } \\
\text { may reduce the degree of renal } \\
\text { reinnervation, the beneficial actions } \\
\text { of renal denervation may still be } \\
\text { offset by denervation supersensitivity. } \\
\text { (Against) }\end{array}$ \\
\hline $\begin{array}{l}\text { Nishihara M, Takesue K, } \\
\text { Hirooka Y (2017) }\end{array}$ & $\begin{array}{l}\text { Bilateral renal } \\
\text { denervation } \\
\text { and bicuculline } \\
\text { microinjection }\end{array}$ & Mice/n=101 & $\begin{array}{l}\text { According to this study, renal } \\
\text { denervation has a sustained } \\
\text { antihypertensive effect by increasing } \\
\text { the urinary sodium excretion levels } \\
\text { in the early phase and inhibiting } \\
\text { SNA in association with augmented } \\
\text { (In favor) GABA-ergic input into } \\
\text { the paraventricular nucleus of the } \\
\text { hypothalamus in the late phase } \\
\text { in hypertensive mice with chronic } \\
\text { kidney disease. (In favor) }\end{array}$ \\
\hline $\begin{array}{l}\text { Yao Y, Davis G, Harrison } \\
\text { JC, Walker RJ, Sammut IA } \\
\text { (2017) }\end{array}$ & $\begin{array}{c}\text { Diabetes induction } \\
\text { and bilateral renal } \\
\text { denervation }\end{array}$ & Rats $/ n=27$ & $\begin{array}{l}\text { Findings of this study support the } \\
\text { conclusions that sympathetic tone is } \\
\text { important in the pathophysiological } \\
\text { development of hypertensive renal } \\
\text { damage in diabetes. (In favor) }\end{array}$ \\
\hline $\begin{array}{l}\text { Veiga GL, Nishi EE, Estrela } \\
\text { HF, Lincevicius GF, Gomes } \\
\text { GN, Sato AYS, Campos RR, } \\
\text { Bergamaschi CT (2017) }\end{array}$ & $\begin{array}{l}\text { Induction of chronic } \\
\text { kidney disease } \\
\text { and total renal } \\
\text { denervation }\end{array}$ & Rats $/ n=44$ & $\begin{array}{l}\text { Data from this study suggest that } \\
\text { hypertension, reduced renal function, } \\
\text { and increased sympathoexcitation } \\
\text { to other targets are at least partially } \\
\text { driven by renal nerves in CKD. } \\
\text { (In favor) }\end{array}$ \\
\hline
\end{tabular}

and clinical aspects of the procedure. The first part of this short review addresses the functional contribution of renal sympathetic nerves for blood pressure control. The second part discusses the pros and cons of renal denervation procedure for the treatment of resistant hypertension.

\section{RENAL SYMPATHETIC INNERVATION: PHYSIOLOGICAL ROLE OF EFFERENT AND AFFERENT FIBERS}

Peripheral neural sympathetic outflow is a regionally differentiated process. This means that a stimulus can increase sympathetic activity in one or more organ or regions and decrease or produce no effect in others. Renal nerves contain both efferent and afferent nerve fibers, also called efferent or afferent renal nerves ${ }^{19-21}$. These nerves lie adjacent to the wall of renal arteries but they are not symmetrically distributed. Indeed, a deep understanding of the microanatomy of renal nerves is necessary for the best cardiovascular results produced by renal denervation ${ }^{22}$. A recent study in humans demonstrated that 1) the right renal artery has significantly higher innervation than the left, 2) the anterior and superior quadrants present higher innervation than the posterior and inferior quadrants, and 3) the distal third of the renal arteries are more innervated than the proximal segments ${ }^{23}$. Therefore, an efficient denervation removes the central sympathetic hyperactivity that will lead to consistent and durable blood pressure reduction.

The efferent fibers carry nerve impulses from the central nervous system towards the kidney influencing kidney function. The main neurotransmitter of the sympathetic efferent terminals is norepinephrine that acts on the vascular and nephron structures ${ }^{20}$. On the other hand, afferent or sensory fibers carry impulses originated in the kidney towards the central nervous system. The majority of the afferent sensory fibers are located in the renal pelvic wall ${ }^{24}$. The traffic of nerve signaling between the central nervous system and kidneys, and vice versa, is known as renal nerve activity (Figure 1B). Therefore, the renal nerve activity contains the efferent renal sympathetic nerve activity (ERSNA) and the afferent renal nerve activity (ARNA). In other words, the so called "nerve activity" is determined by the traffic of action potentials travelling from the brain to the kidney and from the 
kidney to the brain (Figure 1B). Efferent and afferent renal signals can be experimentally identified and measured in mammals ${ }^{25-27}$.

Renal afferent fibers respond to different stimuli, including chemical (e.g., inflammatory mediators), mechanical (e.g., increase in pelvic pressure), and nociceptive (e.g., kidney stones). It is generally accepted that some afferent signals exert a negative feedback on efferent sympathetic signals, constituting an autonomic inhibitory renorenal reflex (Figure 1C). Elevation of the intrarenal pressure increases afferent discharge and results in hypotension mediated by reduction in efferent sympathetic activity ${ }^{28}$. Activation of renal sensory afferent fibers by a high sodium diet decreases efferent sympathetic signals, which increases urinary sodium excretion to maintain sodium homeostasis ${ }^{19}$. Experiments in rats demonstrated that normal saline had little effect on afferent nerve activity, while hypertonic $\mathrm{NaCl}$ elicited an increase in renal afferent nerve activity ${ }^{29}$. On the other hand, experimental evidence shows that the afferent signaling resulting from renal injury increases efferent renal sympathetic activity leading to hyperten$\operatorname{sion}^{30}$. The enhanced or altered afferent renal input to the paraventricular nucleus in disease conditions may be involved in producing elevated sympathetic nerve activity ${ }^{31}$. In addition, evidence indicates that functional ablation of renal afferent fibers does not affect the regulation of arterial pressure in normal conditions but may play a role in the development of salt-sensitive hypertension ${ }^{32}$. In conclusion, there is a reciprocal interaction between efferent and afferent signals, and such interaction certainly depends on the stimulus and kidney condition.

In fact, the physiological contribution of the afferent signaling received little or no attention in the history of sympathetic denervation for hypertension treatment ${ }^{33,34}$. However, with the advent of radiofrequency renal denervation, the interest on renal afferent signaling for blood pressure control has been renewed ${ }^{20,26}$ and a great deal of information will come in the next decade.

Sympathetic efferent fibers are functionally specific in certain target organs. Consistent evidence indicates that this is the case for the kidney, where functionally specific efferent fiber groups could selectively innervate and control the main renal neuroeffectors; the vasculature, the tubules, and the juxtaglomerular granular cells ${ }^{35}$. Therefore, increases in renal sympathetic activity, 1) results in renal vasoconstriction, that consequently, 2) decreases renal blood flow, 3) decreases glomerular filtration rate, 4 ) increases renin release stimulating Ang II formation, and 5) decreases urinary sodium excretion (increases renal tubular sodium reabsorption) ${ }^{35}$.

RENAL SYMPATHETIC INNERVATION IN HYPERTENSION DEVELOPMENT

Hypertension is generally associated with sympathetic hyperactivity ${ }^{36}$ In several situations, hypertension has been attributed to sympathetic overactivity, which can be triggered by afferent signals originating from the kidney and resetting sympathetic tone by stimulation of hypothalamic centers. It has been also considered that ATP receptors contribute to renal vessel hypertrophy during Ang II-induced hyperten$\operatorname{sion}^{37}$. Indeed, Ang II induces rapid release of ATP from sympathetic nerves, acting prejunctionally ${ }^{38}$. This effect of Ang II was very intensively detected in Dahl salt-sensitive rats, suggesting that ATP release from renal sympathetic nerves may contribute to the development of salt-sensitive hypertension ${ }^{39}$.

Chronic activation of renal sympathetic nerves, in both animal and human studies, is critical in the pathogenesis and perpetuation of resistant hypertension. Consequently, renal denervation has emerged as a therapeutic option in disease states characterized by central sympathetic overactivity ${ }^{40,41}$. Renal sympathetic nerves enhance dendritic cell activation, T-cell infiltration, and kidney tissue damage in the development of hypertension ${ }^{42}$. Furthermore, renal sympathetic nerves contribute to hypertension by means of sodium retention, stimulation of renin secretion, and augmentation of sympathetic activity induced by the central nervous system. Based on all these mechanisms, renal denervation has been indicated for the treatment of hypertension, mostly the resistant forms ${ }^{43}$.

\section{RenAl SYMPATHETIC DENERVATION: PROS AND CONS}

Some important questions should be discussed in regard to renal sympathetic denervation: Is the procedure proven to be effective in both animals and humans? Under what conditions can it help? What are the risks? What are the side effects in the short or long term?

\section{EFFICIENCY}

Pre-clinical studies with several animal models of hypertension showed reduction in blood pressure following renal sympathetic denervation ${ }^{44,45,46,47}$. For 
instance, in experimental studies with elderly mice with high systolic blood pressure, there was a drop in blood pressure after the procedure and this effect persisted for many weeks ${ }^{44}$. On the other hand, in younger mice, the fall in blood pressure after denervation was not sustained ${ }^{44}$. In different experimental models of hypertension, renal denervation reduced baseline blood pressure ${ }^{48,45,46,47}$, with concomitant decrease in plasma levels of epinephrine, norepinephrine, renin activity, angiotensin II, and aldosterone ${ }^{49}$. In addition, studies have also suggested that renal denervation improves mechanisms in other target organs including left-ventricular function ${ }^{50}$, endothelial nitric oxide bioavailability ${ }^{51}$, glucose metabolism, and insulin sensitivity $^{52,53}$. Moreover, after renal denervation, heart-failure patients presented improvements in symptoms and exercise capacity ${ }^{54}$. In this regard, Ukena and colleagues found that the cardiorespiratory response in patients submitted to exercise is not affected after renal denervation ${ }^{55}$. The benefits of regular physical activity to reduce cardiovascular risk are well-known ${ }^{56}$. Therefore, improved organ function and preserved exercise capacity after renal denervation can result in better control of hypertension.

However, there is a clear dilemma in proving the efficacy of renal sympathetic denervation based on the results of clinical trials with hypertensive patients. Some clinical trials found the procedure effective, while others questioned its efficac ${ }^{57}$. Authors who speak against the treatment rely on the results of the Symplicity HTN-3 trial ${ }^{12}$. This trial did not find a benefit of renal artery denervation in regard to the reduction of ambulatory blood pressure (BP) in either the 24-hour or day and night periods compared with controls ${ }^{17}$. However, when this trial is critically analyzed, we can find some flaws in its execution. Indeed, the technique of denervation used in the study was inconsistent to determine the effectiveness of the procedure $^{12}$. Retrospective analysis of stored angiographic records of all radio frequency energy applications showed that in $74 \%$ of patients, energy application did not achieve a full circumference of the renal artery, which was a mandatory protocol requirement and should have been bilateral ${ }^{12,58}$. Meanwhile, the SPYRAL HTN-OFF MED study $(\mathrm{n}=38$ in the intervention group and $n=42$ in the sham-operated control group) indicated that the renal sympathetic denervation was effective for the treatment of patients with mild to moderate hypertension (24-h systolic blood pressure (SBP) $-5 \mathrm{~mm} \mathrm{Hg}$ (95\% CI -9.9 to $-0.2 ; p=0.0414), 24-\mathrm{h}$ diastolic blood pressure (DBP) $-4.4 \mathrm{~mm} \mathrm{Hg})^{59}$. However, a critical analysis of that trial suggests that after treatment the patient would still need to take oral antihypertensive therapy to achieve adequate systolic blood pressure levels. In addition, patients with mild to moderate elevation of blood pressure are not recommended for this kind of treatment.

More recently, two trials have investigated the efficacy of renal denervation, the SPYRAL HTN-ON $\mathrm{MED}^{60}$ and the RADIANCE-HTN SOLO ${ }^{61}$

The SPYRAL HTN-ON MED proof-of-concept randomized trial, published in May 2018, aimed to evaluate the safety and efficacy of catheter-based renal denervation compared to sham control for the treatment of uncontrolled hypertension ${ }^{60}$. Patients were submitted to renal angiography and randomly allocated to sham control or renal denervation groups. The primary outcome was blood pressure change from baseline, based on ambulatory blood pressure measurements assessed at 6 months. The Symplicity Spyral multielectrode renal denervation catheter (Medtronic, Galway, Ireland) and the Symplicity G3 renal denervation RF generator (Medtronic, Minneapolis, MN, USA) were used to provide circumferential radiofrequency ablation in a spiral pattern in the four quadrants of the renal artery and of branch vessels between three and eight $\mathrm{mm}$ in diameter. The control group was submitted to a sham. The study had a small number of subjects (38 in the renal denervation group and 42 in the control group) and did not measure the efficiency of renal nerve ablation, although the number of ablations per patient and the technique were similar to those reported in the SPYRAL HTN-OFF MED trial. The study reported a significantly change in BP after 6 months of the procedure in both 24-h SBP and DBP measurements. SBP had a reduction of $-7.4 \mathrm{mmHg}(95 \% \mathrm{CI}-12.5$ to $-2.3 ; p=0.0051)$ and DBP of $-4.1 \mathrm{mmHg}(95 \% \mathrm{CI}$ -7.8 to $-0.4 ; p=0.0292)$. The findings suggested an effect in patients adherent and non-adherent to antihypertensive medications but due to the small sample size the difference between adherent and non-adherent could not be evaluated. Nevertheless, adherence was similar in both groups, and ambulatory BP measurements were obtained only following witnessed pill ingestion in all patients. However, similar to the SPYRAL HTN-OFF-MED trial, the procedure did 
not result in adequate levels of SBP, leading patients to continue using oral antihypertensive therapy ${ }^{60}$. This study is still ongoing and will be completed on December 2022 (available at https://clinicaltrials.gov/ ct2/show/NCT02439749).

The RADIANCE-HTN SOLO trial, also published in 2018, used an endovascular ultrasound renal denervation system in patients with uncontrolled hypertension and in patients with mild to moderate hypertension. Patients were randomized $(1: 1)$ to undergo renal denervation with the Paradise system (ReCor Medical, Palo Alto, CA, USA) or a sham procedure consisting of renal angiography only. Renal nerve ablation was obtained by a minimum of two sonications of 7 seconds each in the main branch of the right and left renal artery, separated longitudinally by $5 \mathrm{~mm}$. The study included 74 patients for renal denervation and 72 for sham procedure. Renal denervation significantly reduced SBP and DBP $(-6.3 \mathrm{mmHg}, 95 \%$ CI -9.4 to $-3.1, p=0.0001$ and $-2.6 \mathrm{mmHg}, 95 \% \mathrm{CI}$ -4.6 to $-0.6, p=0.01$, respectively). The study evaluated only the safety and efficiency of the procedure for two months, in which patients remained off antihypertensive medications. Results were good, but still not enough to permanently stop oral antihypertensive therapy ${ }^{61}$ This trial is still ongoing until August 2021 (available at https:/clinicaltrials.gov/ct2/show/ NCT02649426).

Table 1 summarizes experimental studies and clinical trials evaluating the effect of renal sympathetic denervation for control of arterial hypertension.

\section{RISKS OF THE PROCEDURE AND SIDE EFFECTS}

The potential risks of the procedure include internal hemorrhage, arterial stenosis, and aneurysms, however rarely reported in the literature ${ }^{12}$.

Concerning side effects of the treatment, there are some data to be considered. Previously, there was a $\operatorname{dogma}^{62}$ that the renal sympathetic nerve would only act in the renal blood flow under pathological conditions or by an external stimulation, not occurring under physiological conditions. However, it is now proven that the sympathetic renal nerve has a role also under physiological conditions ${ }^{46}$ and therefore, side effects of the treatment should be expected. For example, renal nerves provide protection against ischemic injuries by limiting ischemia and reperfusion effects on organs susceptible to damage. This effect seems to be impaired after the renal sympathetic denervation treatment ${ }^{63}$.
Other studies indicated that there might be side effects related to cardiac baroreflex, mostly during physical exercise and after sudden postural changes ${ }^{64}$. In these situations, a sudden drop in blood pressure can occur, which may lead to fainting and/or capillary hypoperfusion ${ }^{64}$. Recent evidence also suggests that the procedure can affect the compensatory hemodynamic responses to hemorrhage. Singh and colleagues reported that renal denervation reversed the hypertension in sheep with chronic kidney disease and improved renal function. In response to hemorrhage, the fall in mean arterial pressure was greater in the denervated than the intact group. The increase of heart rate and plasma renin activity were significantly attenuated in sheep submitted to renal denervation when compared with intact sheep ${ }^{65}$.

Besides that, the used technique allows natural sympathetic reinnervation. This nerve regrowth is a troubling condition and is associated with an escape phenomenon, which contributes to the return of hypertension ${ }^{66,67}$. Functional nerve regrowth was also observed in animal trials ${ }^{68}$. It was also suggested that nerve regrowth occurs in native human kidneys after renal transplantation ${ }^{69}$. Due to increased organ sensitization to adrenalin attributed to upregulation of adrenergic receptors, nerve regrowth after denervation leads to the escape phenomenon, since blood pressure increases even more in comparison to levels prior the surgical procedure ${ }^{67}$. In animal studies, rats develop renal norepinephrine super sensitivity and functional reinnervation after perivascular renal denervation ${ }^{68}$. This complication is critical for patients with resistant hypertension and chronic kidney disease.

\section{Concluding Remarks}

Despite animal studies frequently reporting beneficial effects of renal sympathetic denervation for the control of hypertension, results of clinical trials are still somewhat disappointing ${ }^{17,70,71}$. The efficacy of renal denervation for reducing blood pressure in drug-resistant hypertension is currently inconclusive, although it appears to work in some patients ${ }^{72}$. The main limitation is that, even after an apparently successful renal denervation, patients still need to use oral anti-hypertensive medications. In addition, side effects related to the procedure seem not to be a relevant issue, but they should still be taken into account.

It should be mentioned, however, that there are three ongoing clinical trials. The Global Clinical Study of Renal Denervation With the Symplicity Spyral ${ }^{\mathrm{TM}}$ 
Multi-electrode Renal Denervation System in Patients With Uncontrolled Hypertension in the Absence of Antihypertensive Medications (SPYRAL PIVOTAL - SPYRAL HTN-OFF MED) started on June 2015 and will be completed on December 2022 (available at https://clinicaltrials.gov/ct2/show/NCT02439749). The purpose of the study was to test the hypothesis that renal denervation decreases blood pressure and is safe in the absence of antihypertensive medications. Primary outcomes include acute and chronic safety by evaluating incidence of major adverse events from baseline to 1 month post-procedure and changes in SBP measured by 24-hour ambulatory BP monitoring from baseline to 3 months post-procedure. The RADIANCE-HTN is a randomized, double-blind, sham controlled, two cohort studies (TRIO and SOLO) designed to show the efficacy and document the safety of the Paradise Renal Denervation System in two distinct populations of hypertensive subjects (available at https://clinicaltrials.gov/ct2/show/NCT02649426). Subjects with essential hypertension controlled by 1 or 2 antihypertensive medications or uncontrolled will be included in the RADIANCE Solo cohort, whereas subjects with resistant hypertension on a minimum of 3 antihypertensive medications will be included in the RADIANCE Trio cohort. The primary outcome is reduction in average daytime ambulatory SBP from baseline to 2 months after the procedure. The RADIANCE-HTN trial started on March 2016 and will be completed on August 2021. The RADIANCE II Pivotal Study is a randomized trial to test the effectiveness and safety of the Paradise System in subjects with stage 2 hypertension on 0-2 medications at the time of consent (available at https://clinicaltrials. gov/ct2/show/NCT03614260). Prior to randomization, subjects should be hypertensive in the absence of hypertension medication. Primary outcomes are incidence of major adverse events from baseline to 30 days post-procedure and changes in average daytime ambulatory SBP from baseline to 2 months post-procedure. The study started on December 2018 and will be completed on October 2024. Although focused only on short-term effects, these ongoing trials will provide more data on the efficacy and safety of renal denervation.

Finally, the development of devices or surgical procedures for hypertension treatment that interfere with sympathetic nervous system has renewed the importance of sympathetic nerve activity in relation to human cardiovascular control. In this regard, the American Physiological Society recently published a guideline article aiming to provide standard recommendations for measuring sympathetic activity in humans and other mammals ${ }^{73}$. Optimal measurement of sympathetic activity in humans via microneurography can avoid misleading data and incorrect conclusions related to the efficacy of the procedure for a specific group of patients. Further clinical trials adopting standard protocols for the measurement of sympathetic activity in patients submitted to renal sympathetic denervation are needed for the final establishment of the role of this procedure for drug-resistant hypertension.

\section{AcKNoWLedgments}

We would like to thank the financial supporting agencies Conselho Nacional de Desenvolvimento Científico e Tecnológico (M.A.P.F. PQ304388/20173; A.C.S.S. PQ301037/2016-7) and Fundação de Amparo à Pesquisa do Estado de Minas Gerais (FAPEMIG CBB - APQ-01463-15; FAPEMIG CDS APQ-02541-17 and CDS- APQ-04261-17).

\section{References}

1. Benjamin EJ, Blaha MJ, Chiuve SE, Cushman M, Das SR, Deo $\mathrm{R}$, et al. Heart disease and stroke statistics-2017 update: a report from the American Heart Association. Circulation. 2017 Mar 7;135(10):e146-e603.

2. Wang J, Zhang L, Wang F, Liu L, Wang H. Prevalence, awareness, treatment, and control of hypertension in China: results from a national survey. Am J Hypertens. 2014 Nov;27(11):1355-61.

3. Malachias MVB, Póvoa RMS, Nogueira AR, Souza D, Costa LS, Magalhães ME. 7th Brazilian Guideline of Arterial Hypertension: chapter 3-clinical and complementary assessment. Arq Bras Cardiol. 2016 Sep;107(3 Suppl 3):14-7.

4. Fontes MAP, Xavier CH, Marins FR, Limborço-Filho M, Vaz GC, Ribeiro FCM, et al. Emotional stress and sympathetic activity: Contribution of dorsomedial hypothalamus to cardiac arrhythmias. Brain Res. 2014 Mar 20;1554:49-58.

5. Allen AM. Inhibition of the hypothalamic paraventricular nucleus in spontaneously hypertensive rats dramatically reduces sympathetic vasomotor tone. Hypertension. 2002 Feb;39(2):275-80.

6. Silva AQ, Santos RA, Fontes MA. Blockade of endogenous angiotensin-(1-7) in the hypothalamic paraventricular nucleus reduces renal sympathetic tone. Hypertension. 2005 Aug;46(2):341-8.

7. Dibona GF. Sympathetic nervous system and the kidney in hypertension. Curr Opin Nephrol Hypertens. 2002 Mar;11(2):197-200.

8. Schlaich MP, Lambert E, Kaye DM, Krozowski Z, Campbell DJ, Lambert G, et al. Sympathetic Augmentation in Hypertension: Role of Nerve Firing, Norepinephrine Reuptake, and Angiotensin Neuromodulation. Hypertension. 2004 Feb;43(2):169-75.

9. Witkowski A, Prejbisz A, Florczak E, Kadziela J, Sliwinski P, Bielen P, et al. Effects of Renal Sympathetic Denervation on Blood Pressure, Sleep Apnea Course, and Glycemic Control in Patients With Resistant Hypertension and Sleep Apnea. Hypertension. 2011 Oct;58(4):559-65. 
10. Veiga GL, Nishi EE, Estrela HF, Lincevicius GS, Gomes GN, Sato AYS, et al. Total renal denervation reduces sympathoexcitation to different target organs in a model of chronic kidney disease. Auton Neurosci. 2017 May;204:81-7.

11. Calhoun DA, Jones D, Textor S, Goff DC, Murphy TP, Toto $\mathrm{RD}$, et al. Resistant hypertension: diagnosis, evaluation, and treatment : a scientific statement from the American Heart Association Professional Education Committee of the Council for High Blood Pressure Research. Circulation. 2008 Jun 24;117(25):e510-26.

12. Esler M, Guo L. The future of renal denervation. Auton Neurosci. 2017 May;204:131-8.

13. Esler M. Renal denervation for treatment of drug-resistant hypertension. Trends Cardiovasc Med. 2015 Feb;25(2):107-15.

14. Gulati R, Raphael CE, Negoita M, Pocock SJ, Gersh BJ. The rise, fall, and possible resurrection of renal denervation. Nat Rev Cardiol. 2016 Apr;13(4):238-44.

15. Krum H, Schlaich M, Whitbourn R, Sobotka PA, Sadowski J, Bartus K, et al. Catheter-based renal sympathetic denervation for resistant hypertension: a multicentre safety and proof-of-principle cohort study. Lancet. 2009 Apr 11;373(9671):127581.

16. Worthley SG, Tsioufis CP, Worthley MI, Sinhal A, Chew DP, Meredith IT, et al. Safety and efficacy of a multi-electrode renal sympathetic denervation system in resistant hypertension: the EnligHTN I trial. Eur Heart J. 2013 Jul;34(28):2132-40.

17. Bhatt DL, Kandzari DE, O'Neill WW, D'Agostino R, Flack JM, Katzen BT, et al. A controlled trial of renal denervation for resistant hypertension. N Engl J Med. 2014 Apr 10;370(15):1393401.

18. Townsend RR, Mahfoud F, Kandzari DE, Kario K, Pocock S, Weber MA, et al. Catheter-based renal denervation in patients with uncontrolled hypertension in the absence of antihypertensive medications (SPYRAL HTN-OFF MED): a randomised, sham-controlled, proof-of-concept trial. Lancet. 2017 Nov 11;390(10108):2160-70.

19. Booth LC, Nishi EE, Yao ST, Ramchandra R, Lambert GW, Schlaich MP, et al. Reinnervation of Renal Afferent and Efferent Nerves at 5.5 and 11 Months After Catheter-Based Radiofrequency Renal Denervation In Sheep. Hypertension. 2015 Feb;65(2):393-400.

20. Kopp UC. Role of renal sensory nerves in physiological and pathophysiological conditions. Am J Physiol Regul Integr Comp Physiol. 2015 Jan 15;308(2):R79-95.

21. Lambert E, Schlaich M. The role of renal sympathetic nerves in ischemia reperfusion injury. Auton Neurosci. 2017 May;204:105-11.

22. Esler M. Renal denervation for treatment of drug-resistant hypertension. Trends Cardiovasc Med. 2015 Feb;25(2):107-15.

23. Imnadze G, Balzer S, Meyer B, Neumann J, Krech RH, Thale J, et al. Anatomic Patterns of Renal Arterial Sympathetic Innervation: New Aspects for Renal Denervation: Patterns of Renal Arterial Innervation. J Intervent Cardiol. 2016 Dec;29(6):594-600.

24. Marfurt CF, Echtenkamp SF. Sensory innervation of the rat kidney and ureter as revealed by the anterograde transport of wheat germ agglutinin-horseradish peroxidase (WGA-HRP) from dorsal root ganglia. J Comp Neurol. 1991 Sep 15;311(3):389-404.

25. Kopp UC, Cicha MZ, Smith LA, Mulder J, Hökfelt T. Renal sympathetic nerve activity modulates afferent renal nerve activity by PGE2-dependent activation of alpha1- and alpha2-adrenoceptors on renal sensory nerve fibers. Am J Physiol Regul Integr Comp Physiol. 2007 Aug 1;293(4):R1561-72.

26. Osborn JW, Foss JD. Renal Nerves and Long-Term Control of Arterial Pressure. Compr Physiol [Internet]. 2017 Apr; [cited 2017 Sep 15]; 7(2):263-320. Available from: http://doi.wiley. com/10.1002/cphy.c150047

27. Ye S, Zhong H, Yanamadala V, Campese VM. Renal injury caused by intrarenal injection of phenol increases afferent and efferent renal sympathetic nerve activity. Am J Hypertens. 2002 Aug;15(8):717-24.
28. Ueda H, Uchida Y, Kamisaka K. Mechanism of the reflex depressor effect by kidney in dog. Jpn Heart J. 1967 Nov;8(6):597-606.

29. Goodwill VS, Terrill C, Hopewood I, Loewy AD, Knuepfer MM. CNS sites activated by renal pelvic epithelial sodium channels (ENaCs) in response to hypertonic saline in awake rats. Auton Neurosci. 2017 May;204:35-47.

30. Osborn JW, Foss JD. Renal Nerves and Long-Term Control of Arterial Pressure. Compr Physiol. 2017;7(2):263-320.

31. Zheng H, Patel KP. Integration of renal sensory afferents at the level of the paraventricular nucleus dictating sympathetic outflow. Auton Neurosci. 2017 May;204:57-64.

32. Foss JD, Wainford RD, Engeland WC, Fink GD, Osborn JW. A novel method of selective ablation of afferent renal nerves by periaxonal application of capsaicin. Am J Physiol Regul Integr Comp Physiol. 2015 Jan 15;308(2):R112-22.

33. Fishberg AM. Sympathectomy for essential hypertension. JAMA. 1948;137(8):670-675.

34. Smithwick RH, Thompson JE. Splanchnicectomy for essential hypertension: results in 1,266 cases. J Am Med Assoc. 1953 Aug 15;152(16):1501-4.

35. DiBona GF. Neural control of the kidney: functionally specific renal sympathetic nerve fibers. Am J Physiol Regul Integr Comp Physiol. 2000 Nov;279(5):R1517-24.

36. Amann K, Veelken R. Mechanisms and consequences of sympathetic hyperactivity in renal disease. Clin Nephrol. 2003 Jul;(60 Suppl 1):S81-92.

37. Graciano ML, Nishiyama A, Jackson K, Seth DM, Ortiz RM, Prieto-Carrasquero MC, et al. Purinergic receptors contribute to early mesangial cell transformation and renal vessel hypertrophy during angiotensin II-induced hypertension. Am J Physiol Ren Physiol. 2008 Oct 14;294(1):F161-9.

38. Ellis JL, Burnstock G. Angiotensin neuromodulation of adrenergic and purinergic co-transmission in the guinea-pig vas deferens. Br J Pharmacol. 1989 Aug;97(4):1157-64.

39. Palygin O, Levchenko V, Ilatovskaya DV, Pavlov TS, Ryan RP, Cowley Junior AW, et al. Real-time electrochemical detection of ATP and $\mathrm{H} 2 \mathrm{O} 2$ release in freshly isolated kidneys. Am J Physiol Ren Physiol. 2013 Jul 1;305(1):F134-41.

40. Nishi EE, Bergamaschi CT, Campos RR. The crosstalk between the kidney and the central nervous system: the role of renal nerves in blood pressure regulation. Exp Physiol. 2015 Apr;100(5):479-84.

41. Thorp AA, Schlaich MP. Device-based approaches for renal nerve ablation for hypertension and beyond. Front Physiol. 2015 Jul 8;6:193.

42. Xiao L, Kirabo A, Wu J, Saleh MA, Zhu L, Wang F, et al. Renal denervation prevents immune cell activation and renal inflammation in angiotensin II-induced hypertension. Circ Res. 2015 Aug 28;117(6):547-57.

43. Weber MA, Kirtane A, Mauri L, Townsend RR, Kandzari DE, Leon MB. Renal denervation for the treatment of hypertension: making a new start, getting it right. J Clin Hypertens. 2015 Oct;17(10):743-50.

44. Fink GD, Phelps JT. Can we predict the blood pressure response to renal denervation?. Auton Neurosci. 2017 May;204:112-8.

45. O'Hagan KP, Thomas GD, Zambraski EJ. Renal denervation decreases blood pressure in DOCA-treated miniature swine with established hypertension. Am J Hypertens. 1990 Jan;3(1):62-4.

46. Alexander BT, Hendon AE, Ferril G, Dwyer TM. Renal Denervation Abolishes Hypertension in Low-Birth-Weight Offspring From Pregnant Rats With Reduced Uterine Perfusion. Hypertension. 2005 Apr 1;45(4):754-8.

47. Skrzypecki J, Gawlak M, Huc T, Szulczyk P, Ufnal M. Renal denervation decreases blood pressure and renal tyrosine hydroxylase but does not augment the effect of hypotensive drugs. Clin Exp Hypertens. 2017 Apr 3;39(3):290-4.

48. Oliveira VL, Irigoyen MC, Moreira ED, Strunz C, Krieger EM. Renal denervation normalizes pressure and baroreceptor reflex in high renin hypertension in conscious rats. Hypertension. 1992;19(2 Suppl):II17-21. 
49. Li D, Wang Q, Zhang Y, Li D, Yang D, Wei S, et al. A Novel Swine Model of Spontaneous Hypertension With Sympathetic Hyperactivity Responds Well to Renal Denervation. Am J Hypertens. 2016 Jan;29(1):63-72.

50. Schirmer SH, Sayed MM, Reil JC, Ukena C, Linz D, Kindermann $\mathrm{M}$, et al. Improvements in left ventricular hypertrophy and diastolic function following renal denervation: effects beyond blood pressure and heart rate reduction. J Am Coll Cardiol. 2014 May 13;63(18):1916-23.

51. Polhemus DJ, Gao J, Scarborough AL, Trivedi R, McDonough $\mathrm{KH}$, Goodchild TT, et al. Radiofrequency renal denervation protects the ischemic heart via inhibition of GRK2 and increased nitric oxide signaling. Circ Res. 2016 Jul 22;119(3):470-80.

52. Mahfoud F, Schlaich M, Kindermann I, Ukena C, Cremers B, Brandt MC, et al. Effect of renal sympathetic denervation on glucose metabolism in patients with resistant hypertension: a pilot study. Circulation. 2011 May 10;123(18):1940-6.

53. Witkowski A, Prejbisz A, Florczak E, Kądziela J, Śliwiński $\mathrm{P}$, Bieleń P, et al. Effects of renal sympathetic denervation on blood pressure, sleep apnea course, and glycemic control in patients with resistant hypertension and sleep apnea. Hypertension. 2011;58(4):559-65.

54. Davies JE, Manisty CH, Petraco R, Barron AJ, Unsworth B, Mayet J, et al. First-in-man safety evaluation of renal denervation for chronic systolic heart failure: primary outcome from REACH-Pilot study. Int J Cardiol. 2013 Jan 20;162(3):189-92.

55. Ukena C, Mahfoud F, Kindermann I, Barth C, Lenski M, Kindermann $\mathrm{M}$, et al. Cardiorespiratory response to exercise after renal sympathetic denervation in patients with resistant hypertension. J Am Coll Cardiol. 2011 Sep 6;58(11):1176-82.

56. Warburton DE, Bredin SS. Reflections on physical activity and health: what should we recommend?. Can J Cardiol. 2016 Apr;32(4):495-504.

57. Fernández-Ruiz I. Hypertension: Proof of concept for renal denervation. Nat Rev Cardiol. 2017 Nov;14(11):634.

58. Kandzari DE, Bhatt DL, Brar S, Devireddy CM, Esler M, Fahy $\mathrm{M}$, et al. Predictors of blood pressure response in the SYMPLICITY HTN-3 trial. Eur Heart J. 2014 Jan 21;36(4):219-27.

59. Azizi M. Catheter-based renal denervation for treatment of hypertension. Lancet. 2017 Nov 11;390(10108):2124-6.

60. Kandzari DE, Böhm M, Mahfoud F, Townsend RR, Weber MA, Pocock S, et al. Effect of renal denervation on blood pressure in the presence of antihypertensive drugs: 6-month efficacy and safety results from the SPYRAL HTN-ON MED proof-of-concept randomised trial. Lancet. 2018 Jun 9;391(10137):2346-55.
61. Azizi M, Schmieder RE, Mahfoud F, Weber MA, Daemen J, Davies J, et al. Endovascular ultrasound renal denervation to treat hypertension (RADIANCE-HTN SOLO): a multicentre, international, single-blind, randomised, sham-controlled trial. Lancet. 2018 Jun 9;391(10137):2335-45.

62. DiBona GF, Kopp UC. Neural control of renal function. Physiol Rev. 1997 Jan;77(1):75-197.

63. Phillips JK, Campos RR. Role of renal nerves in normal and pathophysiological conditions. Auton Neurosci. 2017 May;204:1-3.

64. Schiller AM, Pellegrino PR, Zucker IH. Eppur Si Muove: the dynamic nature of physiological control of renal blood flow by the renal sympathetic nerves. Auton Neurosci. 2017 May;204:17-24.

65. Singh RR, Sajeesh V, Booth LC, McArdle Z, May CN, Head $\mathrm{GA}$, et al. Catheter-based renal denervation exacerbates blood pressure fall during hemorrhage. J Am Coll Cardiol. 2017 Feb 28;69(8):951-64.

66. McBryde FD, Hart EC, Ramchandra R, Paton JF. Evaluating the carotid bodies and renal nerves as therapeutic targets for hypertension. Auton Neurosci. 2017 May;204:126-30.

67. Grisk O. Renal denervation and hypertension - The need to investigate unintended effects and neural control of the human kidney. Auton Neurosci. 2017 May;204:119-25.

68. Kline RL, Mercer PF. Functional reinnervation and development of supersensitivity to $\mathrm{NE}$ after renal denervation in rats. Am J Physiol. 1980 May;238(5):R353-8.

69. Dobrowolski LC, Verberne HJ, van den Born BJH, ten Berge IJ, Bemelman FJ, Krediet CP. Kidney transplant (123)I-mIBG scintigraphy and functional sympathetic reinnervation. Am J Kidney Dis. 2015 Sep;66(3):543-4.

70. Briasoulis A, Bakris G. Renal denervation after SYMPLICITY HTN-3: where do we go?. Can J Cardiol. 2015 May;31(5):6428.

71. Laffin LJ, Bakris GL. Renal denervation for resistant hypertension and beyond. Adv Chronic Kidney Dis. 2015 Mar;22(2):133-9.

72. Gosain P, Garimella PS, Hart PD, Agarwal R. Renal sympathetic denervation for treatment of resistant hypertension: a systematic review. J Clin Hypertens (Greenwich). 2013 Jan;15(1):75-84.

73. Hart EC, Head GA, Carter JR, Wallin BG, May CN, Hamza $\mathrm{SM}$, et al. Recording sympathetic nerve activity in conscious humans and other mammals: guidelines and the road to standardization. Am J Physiol Heart Circ Physiol. 2017 May 1;312(5):H1031-51. 